\title{
Electrochemical Studies on Speciation of Cadmium(II) in ppb Level by Complexation with Ethylenediamine in Aqueous Media
}

\author{
Nurun Nahar*, Anshaya Ramim and M. Nurul Abser \\ Department of Chemistry, Jahangirnagar University, Savar, Dhaka-1342, Bangladesh.
}

\begin{abstract}
The speciation of cadmium(II) in ppb level by complexation with ethylenediamine (EN) has been investigated by differential pulse anodic stripping voltammetry (DPASV) using thin mercury film coated glassy carbon electrode (TMFGCE). The overall work has been carried out at constant ionic strength of $0.01 \mathrm{~mol} \mathrm{dm}^{-3}\left(\mathrm{NaNO}_{3}\right)$ at ambient temperature. The $\mathrm{pH}$ was kept constant at $8.81 \pm 0.10$ by the addition of borate buffer. The stability constants of different species of cadmium(II) with ethylenediamine have been calculated from the variation of peak potential and diffusion current of simple and complexed metal ions under the present experimental conditions. The logarithmic values of overall stability constants: $\log \beta_{1}, \log \beta_{2}$ and $\log \beta_{3}\left(\beta_{\mathrm{i}}=\left[\mathrm{CdL}_{\mathrm{i}}\right] /\left[\mathrm{Cd}^{2+}\right][\mathrm{L}]^{\mathrm{i}}\right.$ where $\mathrm{i}=1,2$ and 3$)$ have been found to be 5.01 , 8.9 and 11.1 for $\mathrm{CdL}, \mathrm{CdL}_{2}$ and $\mathrm{CdL}_{3}$, respectively (charges were omitted for simplicity). The stability constants of cadmium complexes and hydrolysis constants of cadmium indicate that five different species of cadmium $\left(\mathrm{Cd}^{2+}, \mathrm{CdOH}^{+}, \mathrm{CdL}, \mathrm{CdL}_{2}\right.$ and $\left.\mathrm{CdL}_{3}\right)$ co-exist at ligand concentrations up to $5 \times 10^{-}$

${ }^{4}$ mole $\mathrm{dm}^{-3}$ under the present experimental conditions. The results obtained by this method is applied to study the cadmium speciation in river water on the basis of competitive ligand exchange equilibrium.
\end{abstract}

Key words: Speciation, Complexation, Aqueous media, DPASV, Mercury film electrode.

\section{Introduction}

Cadmium is considered as one of the most toxic element in the environment. At high levels, it causes painful osteomalacia (bone disease), bone marrow disorders, kidney problems, "Itai Itai" or "Ouch ouch", diseases, etc (De, 1999). It causes adverse effects in fish and wildlife, if its concentra- tion exceeds $3 \mathrm{ppb}$ in fresh water and $4.5 \mathrm{ppb}$ in saline water. It adversely affects several important enzymes. It is now well known that the toxicity of metal depends not only on the total dissolved concentrations but also their chemical form i.e. chemical speciation. The free $\mathrm{Cd}^{2+}$ concentrations control the

* Corresponding author: E-mail: naharn@bangla.net 
intake of cadmium by organisms (Ahner et al, 1994; Brand et al, 1986; Hare and Tessier, 1996; Lee et al, 1996). The speciation study using ligand exchange equilibrium method is suitable to calculate the free $\mathrm{Cd}^{2+}$ concentration in freshwater as well as saline water system.

Since the stability constants for metal complexes are useful to calculate the relative proportions of different forms of metal present in aqueous system, it is, intended to elucidate the equilibrium constants of the complexes between cadmium(II) (in ppb level) with ethylenediamine under laboratory condition. The result obtained by this investigation will be applied to the study of speciation and complexation of cadmium by natural ligand based on competitive ligand exchange equilibrium.

Voltammetric techniques are widely used to study the interaction of metal with organic ligands due to its very high reproducibility and reliability at very low concentration (Buffle, 1988; Kissinger and Heinemann, 1996; Nahar, 2003). Other methods are also available for the evaluation of the complexing properties of metal ions in aqueous solutions. For example, visible absorption spectrophotometry (Darj and Malinowski, 1996), potentiometry (Corrie et al, 1976), isotopic exchange, ion-selective electrode (Stiff, 1971; Gardiner, 1974) etc. However, these methods have insufficient sensitivity for reliable measurement of metal species at very low concentration of metal ion in the aque- ous medium. Recently differential pulse anodic stripping voltammetry has been extensively used to determine the equilibrium constant of the complex between metal ion and organic ligands at ppb level in the aqueous medium.

\section{Materials and Methods}

\section{Equipment and Reagents}

The differential pulse anodic stripping voltammetric measurement for the determination of the stability constant of Cd(II) in ppb level with ethylenediamine has been carried out by computer controlled electrochemical analyzer (Model: HQ-2040, Advanced Analytics, USA). The analyzer is coupled with a computer controlled magnetic stirrer and an electrochemical cell consisting of three electrodes: $3 \mathrm{~mm}$ glassy carbon electrode, $\mathrm{Ag} / \mathrm{AgCl}$. KCl reference electrode and $\mathrm{Pt}$ counter electrode as described earlier (Nahar et al, 2000).

To prepare mercury film, the stock solution of $\mathrm{HgCl}_{2}$ was prepared by dissolving required amounts of $\mathrm{HgCl}_{2}$ into $0.1 \mathrm{~mol}$ $\mathrm{dm}^{-3} \mathrm{HCl}$ solution. A $1000 \mu \mathrm{g} / \mathrm{mL}$ stock solution of cadmium(II) was prepared by dissolving required amounts of $\mathrm{Cd}\left(\mathrm{NO}_{3}\right)_{2}$ in $0.1 \mathrm{~mol} \mathrm{dm}^{-3} \mathrm{HNO}_{3}$ solution. Another stock solution of $1.0 \mathrm{~mol} \mathrm{dm}^{-3}$ ethylenediamine was prepared in distilled and deionized water. Metal contamination was eleminated from the ligand solution by shaking the solution with small quantities of granular $\mathrm{MnO}_{2}$ 
and filtering it with $0.40 \mu \mathrm{m}$ membrane filter (Van den Berg, 1984) to remove particulates. Ionic strength of the solution was maintained constant using $0.1 \mathrm{~mol} \mathrm{dm}{ }^{-3} \mathrm{NaNO}_{3}$ (99.99\%) solution. The required standard solutions were prepared once a week by dilution of the stock solutions. All stock solutions were stored in the refrigerator at $4^{\circ} \mathrm{C}$.

\section{Preparation of mercury film on glassy carbon electrode}

Mercury film was prepared on properly polished and washed glassy carbon electrode in $10 \mathrm{~mL}$ of $1.0 \times 10^{-3} \mathrm{~mol} \mathrm{dm}^{-3}$ mercury(II) solution. The solution was purged with nitrogen for 10 minutes to remove dissolved oxygen. Then the electrodes were connected to the analyzer. Any bubbles adhering to the electrodes were removed by tapping them off. The mercury film deposition was done at $-400 \mathrm{mV}$ for $6 \mathrm{~min}$ by applying differential pulse voltammetry program.

Theory and data treatment for the determination of the stability constant

In aqueous solution, the formation of a complex between metal ion, $\mathrm{M}^{\mathrm{n}+}$ and organic ligand, $\mathrm{L}$ give the complex ML (the overall charge of the complex is omitted for simplicity). The reaction occurs in several steps as follows:

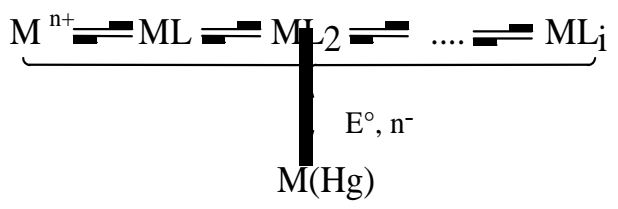

where the metal ion can be reversibly reduced on a mercury film electrode.

The differential pulse anodic stripping voltametric measurement of peak current and peak potential induced by increasing ligand concentration allows the determination of overall conditional stability constant of complexes in solution. The stability constant of various species of cadmium(II) with ethylenediamine can be calculated according to the model of DeFord and Hume (DeFord and Hume, 1951) on the basis of the change in peak potential with ligand concentration as described before (Nahar, 1999, 2003). According to their model, the overall conditional stability constant of individual complexes containing $1,2, \ldots, n$ number of ligands are related to the formation function as follows:

$\mathrm{F}_{0}=\exp \left(-\frac{n F}{R T} \Delta E+1 n \frac{I_{\text {free }}}{I_{\text {complexed }}}\right)=1+\sum_{i=1}^{N} \beta_{i}[L]^{i}$

where $\Delta \mathrm{E}$ is the change in peak potential between simple and complexed metal ions, $\mathrm{I}_{\text {free }}$ and $\mathrm{I}_{\text {complexed }}$ are the peak currents of simple and complexed metal ions, respectively, $\mathrm{n}=$ number of electrons involved in the redox reaction, $\mathrm{F}=$ Faraday constant, $\mathrm{R}=$ gas constant, $[\mathrm{L}]=$ free ligand concentration (not bound with proton) and $i=1,2, \ldots, N$. The successive formation constants $\left(\beta_{\mathbf{i}}\right)$ are evaluated by polynomial fitting of the zero-order Leden function $\mathrm{F}_{0}$. The values of $\mathrm{F}_{0}$ can be calculated from the experimental change in 
peak potential and peak currents for each values of [L] in the voltammetric titration using equation 2 .

The free ligand concentrations, [L] are computed from the protonation constants at experimental $\mathrm{pH}$ as follows:

$$
[\mathrm{L}]=\mathrm{C}_{\mathrm{L}}\left(1+\left[\mathrm{H}^{+}\right] \mathrm{K}_{1}+\left[\mathrm{H}^{+}\right]^{2} \mathrm{~K}_{1} \mathrm{~K}_{2}\right)^{-1}
$$

where $\mathrm{C}_{\mathrm{L}}$ represents the total concentration of ligand and $K_{1}$ and $K_{2}$ are the protonation constants of ethylenediamine.

The overall conditional stability constant of each species with respect to labile metal ion is determined using nonlinear fitting program on Equation 2. The overall stability constant with respect to free metal ion is obtained by considering the inorganic side reaction coefficient of cadmium $\left(\alpha_{\mathrm{Cd}}\right)$ at $\mathrm{pH}$ $8.81 \pm 0.10$.

\section{Results and Discussion}

The voltammogram of $100 \mathrm{ppb}\left(\mu \mathrm{g} \mathrm{dm} \mathrm{dm}^{-3}\right)$ $\mathrm{Cd}(\mathrm{II})$ solution at $\mathrm{pH} 8.81 \pm 0.10$ and ionic strength $0.01 \mathrm{~mol} \mathrm{dm}^{-3}$ was recorded. The peak of the unchelated cadmium(II) appeared at $-627 \mathrm{mV}$. The value of the peak potential depends on $\mathrm{pH}$ and the composition of the reference electrode. The peak potential was shifted to more negative potential after successive addition of ethylenediamine in the reaction cell, indicating that the complexation occured between cadmium(II) and ethylenediamine. The peak current of cadmium(II) was decreased with increasing the concentration of ethylenediamine in the medium. This behavior also indicated the formation of the complexes between cadmium(II) and ethylenediamine under the present experimental condition. A typical change of voltammograms with ligand concentration is shown in Fig. 1. The plot of peak

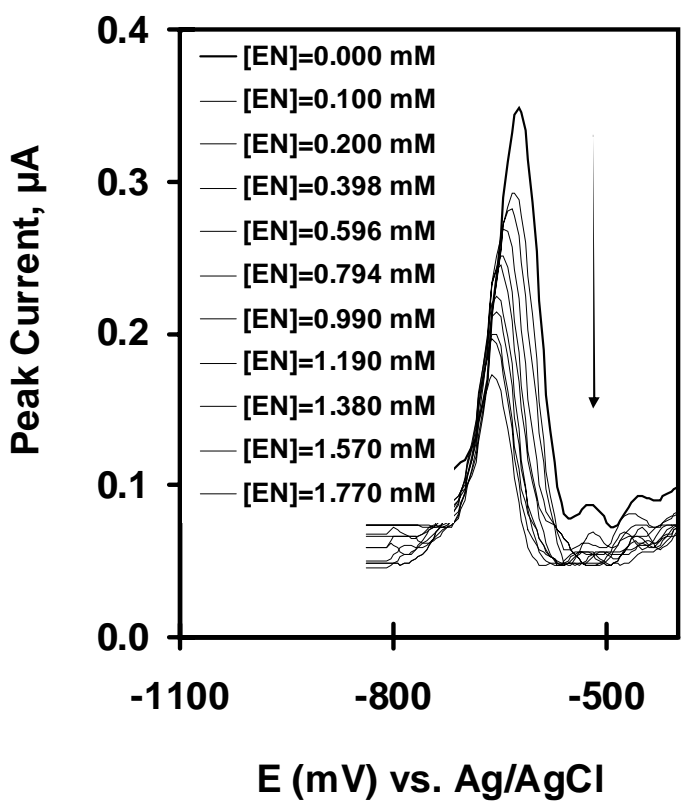

Fig. 1: Voltammograms of cadmium after successive addition of varying concentration of ethylenediamine (EN); [Cadmium(II) $]=0.89 \mu \mathrm{M},[\mathrm{EN}]=\mathbf{0 . 0 0}$ to $1.77 \mu \mathrm{M}, \mathrm{pH}=\mathbf{8 . 8} \pm \mathbf{0 . 1}$ and $\mathrm{I}=\mathbf{0 . 0 1}$ $\mathrm{M}\left(\mathrm{NaNO}_{3}\right)$

potential vs $\log \mathrm{i} /\left(\mathrm{i}_{\mathrm{d}}-\mathrm{i}\right)$ gives the straight line (Fig. 2) with a slope of $0.03 \mathrm{~V}$ indicating the number of electron taking part in the reduction process is 2 . The straight line in Fig. 2 also indicates the reduction of metal to $\mathrm{M}(\mathrm{Hg})$ on MFE is a reversible process. The nonlinear curve obtained from the plot of 


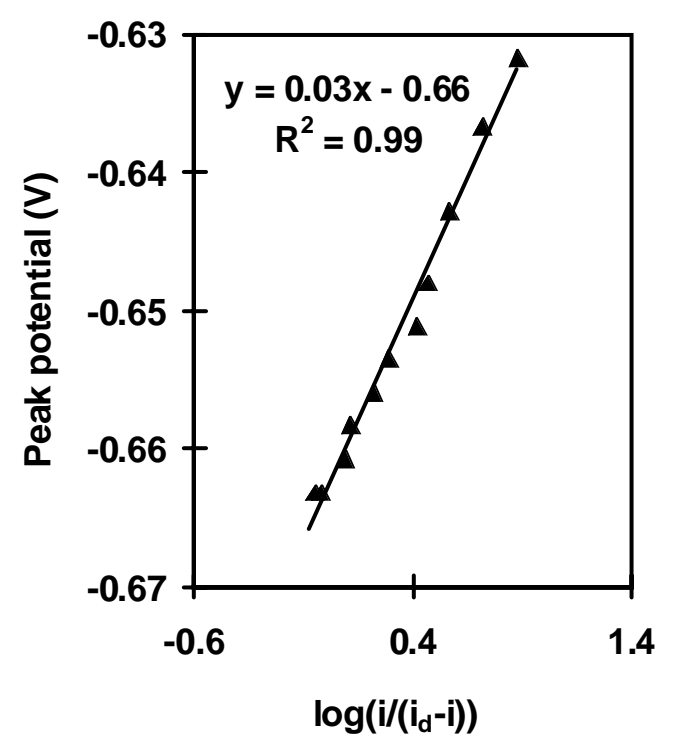

Fig.2: A plot of peak potential vs. $\log \mathbf{i} /\left(\mathbf{i}_{d}-\mathbf{i}\right)$ for cadmium-ethylenediamine complexes when $\left[\right.$ Cadmium(II)] $=8.90 \times 10^{-7} \mathrm{M}$, $[\mathrm{EN}]_{\text {total }}=0.00$ to $1.96 \times 10^{-3} \mathrm{M}, \mathrm{pH}=8.8$ \pm 0.1 and $\mathrm{I}=0.01 \mathrm{M}\left(\mathrm{NaNO}_{3}\right)$

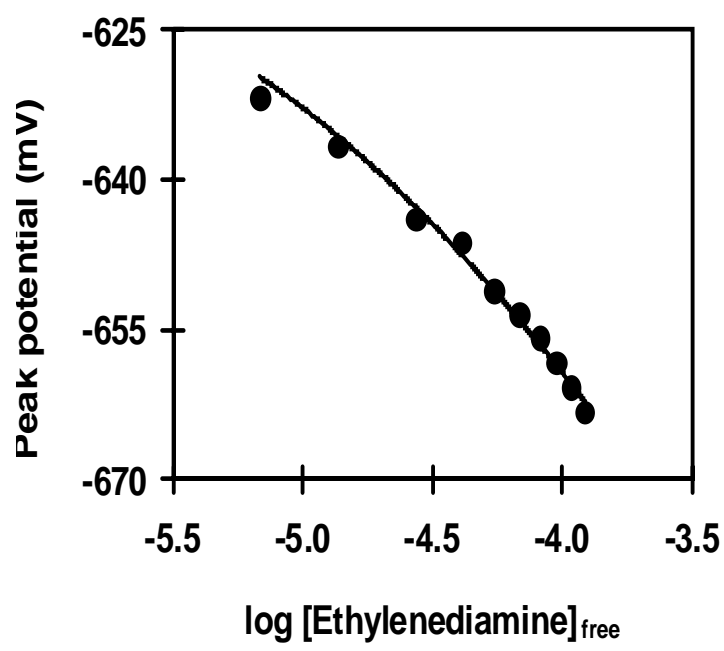

Fig. 3: Plot of peak potential vs. $\log [$ Ethylenediamine $_{\text {free; }}$ [Cadmium(II)] $=0.89 \mu \mathrm{M}$, $\mathrm{pH}=8.8 \pm 0.1$ and $\mathrm{I}=0.01 \mathrm{M}\left(\mathrm{NaNO}_{3}\right)$ peak potential vs. concentration of ligands shown in Fig. 3 indicates that more than one complexes, in equilibrium with each other are formed. The plot of $\mathrm{F}_{0}$ vs. [ethylenediamine $]_{\text {free }}$ shown in Fig. 4, gives the values of conditional stability constants of individual complexes. The stability constant of each species with respect to free metal ion was calculated by considering the side reaction coefficient of cadmium at higher $\mathrm{pH}$ and listed in Table I.

Ethylenediamine (EN) generally acts as a bidentate ligand with most of the metal ions forming mono, bis and tris complexes via $\mathrm{N}$ donor atom. It can exist in three different forms in solution: the monoprotonated (HL), diprotonated $\left(\mathrm{H}_{2} \mathrm{~L}\right)$ and free form (L) depending on $\mathrm{pH}$ of the solution. Since the protonation constants of ethylenediamine, $\mathrm{K}_{1}=[\mathrm{HL}]\left[\mathrm{H}^{+}\right]^{-1}[\mathrm{~L}]^{-1}=10^{9.928}$ and $K_{2}=\left[\mathrm{H}_{2} \mathrm{~L}\right]$ $\left[\mathrm{HL}^{-1}[\mathrm{H}]^{-1}=10^{6.848}\right.$ (Martell and Smith, 1982), only $6.86 \%$ free ethylenediamine is possible to exist at $\mathrm{pH}$ 8.81. Distribution of ethylenediamine as a function of $\mathrm{pH}$ in aqueous media is shown in Fig. 5.

The polynomial fitting of the $\mathrm{F}_{\mathrm{O}}$ function to experimental data showed the presence of 1:1, 1:2 and 1:3 complexes. The logarithmic values of overall stability constants, $\log \beta_{1}$, $\log \beta_{2}$ and $\log \beta_{3}$ were found to be 5.01, 8.9 and 11.1 for $\mathrm{CdL}, \mathrm{CdL}_{2}$ and $\mathrm{CdL}_{3}$, respectively. Only small differences with the literature values shown in Table I are possibly 
Table I. Comparison of stability constants of cadmium-ethylendiamine complexes estimated by various methods

\begin{tabular}{l|l|c|c|c|c}
\hline $\begin{array}{c}\text { Ionic } \\
\text { Strength (M) }\end{array}$ & Temp, ${ }^{\circ} \mathrm{C}$ & $\log / \beta_{1}$ & $\log \beta_{2}$ & $\log \beta_{3}$ & References \\
\hline 0.00 & 25 & 5.40 & 9.90 & 11.7 & $\begin{array}{c}\text { Morel and Hering } \\
\text { Stumm and Morgam, 1993; } \\
0.01\end{array}$ \\
0.10 & 25 & 5.01 & 8.94 & 11.1 & $\begin{array}{c}\text { This work } \\
1.00\end{array}$ \\
\hline
\end{tabular}

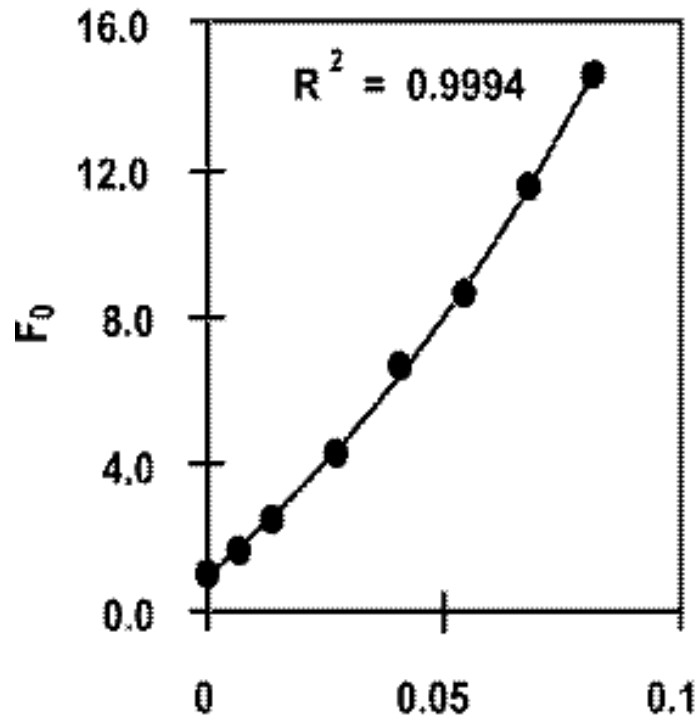

[Ethylenediamine] free, $\mathrm{mM}$

Fig. 4: The variation of $F_{0}$ as a function of concentration of free ethylenediamine; [Cadmium(II) $]=0.89 \mu \mathrm{M}, \quad \mathrm{pH}=8.8 \pm$ 0.1 and $\mathrm{I}=0.01 \mathrm{M}\left(\mathrm{NaNO}_{3}\right)$ due to the difference in ionic strength or different $\mathrm{pK}$ values of ethylenediamine reported by different investigators (Morel and Hering, 1993; Kounaves and Zirino, 1979,

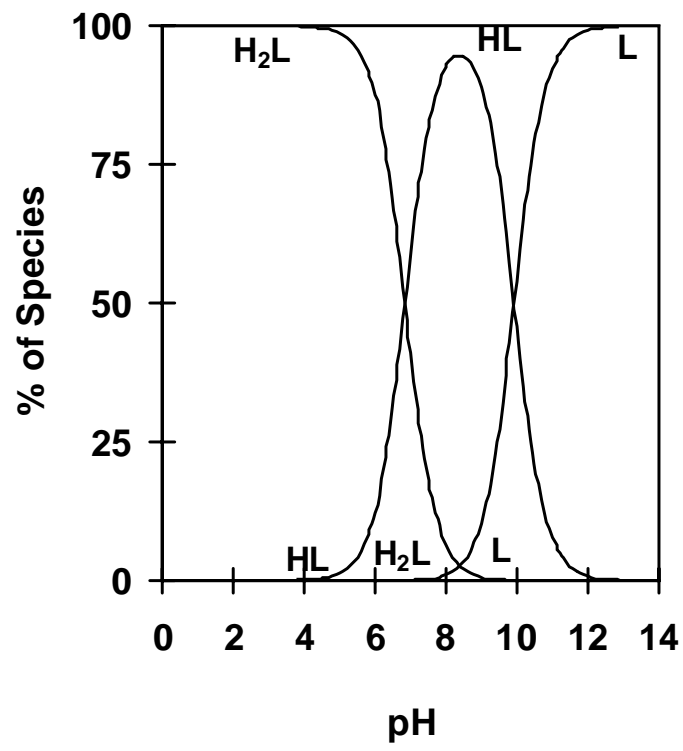

Fig. 5. Species distribution of ethylenediamine as a function of $\mathbf{p H}$. 
Martell and Smith, 1982, Stumm and Morgan, 1995).

In the present experiment, DPASV technique detects the labile species of cadmium(II) which consists of free hydrated form of cadmium(II) (i. e. $\left.\mathrm{Cd}\left(\mathrm{H}_{2} \mathrm{O}\right)_{\mathrm{x}}{ }^{2+}\right)$ and hydroxo complexes $\left(\mathrm{Cd}^{+} \mathrm{OH}\right.$ and $\left.\mathrm{Cd}(\mathrm{OH})_{2}\right)$. This implies that the technique detects a conditional constant that takes into account the side reaction of cadmium(II). Thus, it is necessary to consider the side reaction of $\mathrm{Cd}^{2+}$ with $\mathrm{OH}^{-}$at higher $\mathrm{pH}$. According to the hydrolysis constants of cadmium (Martell and Smith, 1982), mono- and dihydroxy cadmium are possible to be formed.

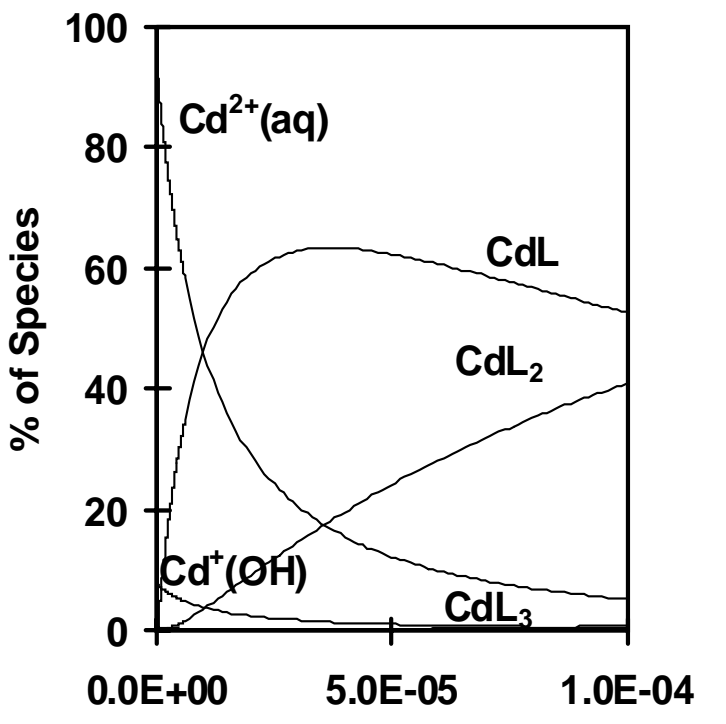

[Ethylenediamine] $]_{\text {total, }}$ M

Fig. 6. Species distribution of cadmium as a function of concentration of ethyl enediamine at $\mathrm{pH} 8.8 \pm 0.1$
In the present experimental conditions, $95 \%$ cadmium exists as free hydrated form and 4.8\% exists as $\mathrm{CdOH}^{+}$and $0.2 \%$ exists as $\mathrm{Cd}(\mathrm{OH})_{2}$ at $\mathrm{pH} 8.8$ in the absence of ethylenediamine shown in Fig. 6. The amount of hydrated species decreased with increasing ethylenediamine concentration. Using the measured stability constants of cadmiumethylenediamine complexes, the percentages of all chemical species were calculated and their variations with concentration of ethylenediamine are shown in Fig. 6.

Because of the higher toxicity of cadmium, the complexation capacity of cadmium was investigated in river water of Bangladesh in presence of ethylenediamine on the basis of competitive ligand exchange equilibrium. The conditional stability constant of cadmium with natural organic ligand (L) was found to be $10^{8.74}$ for the river water of the Meghna. This value is comparable to the reported value $\left(10^{8.36}\right)$ obtained by direct method (Kutubi, 2005).

Using the hydrolysis constants of cadmium and conditional stability constant of cadmium complex with naturally occurring organic ligands, it was computed that $97 \%$ of total cadmium exists as complexed form and only $2.32 \%$ of total cadmium exists as free hydrated form in the river water of the Meghna. These studies are in progress in our 
laboratory and the results will be reported elsewhere.

\section{Conclusions}

The complexation and speciation of traceamount of cadmium in presence of ethylenediamine was investigated at $\mathrm{pH} 8.8$ by DPASV using thin mercury film glassy carbon electrode. The method enables us to determine the stability constants of cadmium complexes at ppb level at higher $\mathrm{pH}$. In the absence of ligand, cadmium mainly exists as hydrated form, whereas in presence of ethylenediamine (EN), it forms 1:1, 1:2 and 1:3 (metal: EN) complexes depending on ligand concentration. All cadmium species (complexed and hydrolysed) appear to co-exist within ligand concentration of up to $5 \times 10^{-4}$ mol $\mathrm{dm}^{-3}$ under the present experimental conditions. Cadmium present in river water also forms stable complex with naturally occurring organic ligands. It was computed that about $97 \%$ of total cadmium exists in complexed form in natural water in presence of $1 \times 10^{-5} \mathrm{~mol} \mathrm{dm}^{-3}$ ethylenediamine and only $2.32 \%$ exists as free hydrated form indicating less toxicity of cadmium to aquatic life.

\section{Acknowledgement}

The authors gratefully acknowledge the Ministry of Information and Science \& Communication Technology, People's
Republic of Bangladesh for financial support.

\section{References}

Ahner, B.A. Price, N.M. Morel, F.M.M. (1994). Phytochelatin production by marine phytoplankton at low free metal ion concentrations: laboratory studies and field data from Massachusetts bay, Proc. Natl. Acad. Sci., 91: 8433-8436.

Buffle, J. (1978). Complexation reaction in aquatic system: An analytical approach, Ellis Horwood, Chichester, pp. 467-562.

Brand, L.E. Sunda, W.G. Guillard, R.R.L. (1986). Reduction of marine phytoplankton reproduction rates by copper and cadmium. $J$. Exp. Mar. Biol. Ecol. 96: 225-250.

Corrie, A.M. Walker, M.D. Williams, D.R. (1976). Thermodynamic considerations. Part XXII. Sequestering ligands for improving the treatment of plumbism and cadmiumism. J. Chem. Soc., Dalton Trans., 10121015.

De, A.K. (1999). Environmental Chemistry, New age international Ltd., pp. 80-81.

DeFord, D.D. Hume, D.N. (1951). The Determination of consecutive formation constants of complex ions from polarographic data. $J$. Amer. Chem. Soc., 73: 5321-5322. 
Darj, M.M. Malinowski, E.R. (1996). Complexation between copper(II) and glycine in aqueous acid solutions by window factor analysis of visible spectra. Anal. Chem., 68: 1593-1598.

Gardiner, H. (1974). The chemistry of cadmium in natural water-I: A study of cadmium complex formation using the cadmium specificion electrode, Water Res., 8: 23-30.

Hare, L. Tessier, A. (1996). Predicting animal cadmium concentrations in lakes; Nature 380: $430-432$.

Kounaves, S.P. Zirino, A. (1979). Studies of cadmium-ethylenediamine complex formation in seawater by computer-assisted stripping polarography. Anal. Chim. Acta, 109: 327339.

Kissinger, P.T. Heinemann, W.R. (1996). Laboratory Techniques in Electroanalytical Chemistry, Marcel Dekker. New York.

Kutubi, M.S. (2005). Preconcentration of lead and cadmium in aqueous media using functionalized Amberlite XAD-16 resin and their speciation in the river water of Bangladesh, M.Sc. Thesis, Jahangirnagar University.

Lee, J.G. Beth, B.A. Morel, F.M.M. (1996). Export of cadmium and phytochelatin by the marine diatom Thalassiosira
Weissflogii, Environ. Sci. Technol., 30 (6): $1814-1821$.

Morel, F.M.M. Hering, J.G. (1993). Principles and Applications of Aquatic Chemistry, Wiley-Interscience, New York, p. 374.

Martell, A.E. Smith, R.M. (1982). Critical Stability Constants, Plenum Press, New York, 5: 142-143.

Nahar, N. Chowdhury, M.N. Khan, A.H. (1999). Complexation and chemical speciation of trace metals in aqueous media. J. Bang. Chem. Soc., 12: 173-183.

Nahar, N. Hamza, M.A., Akhter, F.Tarafder, S.A. (2000). Electrochemical speciation of arsenic by complexation with glycine, cysteine and catechol in aqueous media. $J$. Bang. Chem. Soc., 13: 93-106.

Nahar, N. (2003a). Electrochemical study of speciation of lead(II) in aqueous solution in ppb level in presence of cysteine. Jahangirnagar University Journal of Science, 26: 55-66.

Nahar, N. (2003b). Electrochemical studies of copper(II) complexation capacity and speciation in lake and river water. J. Bang. Chem. Soc., 16(2): 154-164.

Stiff, M.J. (1971). Copper/bicarbonate equilibria in solutions of bicarbonate ion at concentra- 
tions similar to those found in natural water. Water Res., 5: 171-176.

Stumm, W. Morgan, J.J. (1995). Aquatic Chemistry, Chemical Equilibria and Rates in Natural Waters. Wiley-Interscience, New York, pp. 325-334.

Van den Berg, C.M.G. (1984). Determination of the complexing capacity and conditional stability constants of complexes of copper(II) with natural organic ligands in sea water by cathodic stripping voltammetry of copper catechol complex ions. Marine Chemistry, 15: 1-18.

Received : January, 31, 2008;

Accepted : July, 23, 2008. 
Ionic strength (M) $\quad \mathrm{Temp}^{\circ}{ }^{\circ} \mathrm{C}$

$\log \mathrm{b} 1 \quad \log \mathrm{b} 2 \quad \log \mathrm{b} 3 \quad$ References

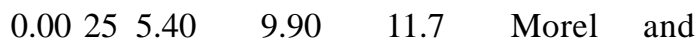
Hering, 1993;Stumm and Morgan, 1995

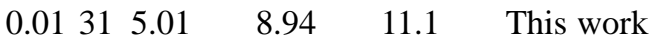

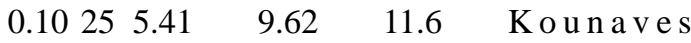
and Zirino, 1979; Martell and Smith, 1982

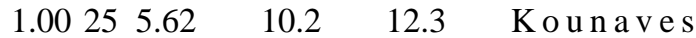
and Zirino, 1979; Martell and Smith, 1982

Figure Captions:

Fig.2: A plot of peak potential vs. log i/(id-i) for cadium-ethylenediamine complexes when [Cadmium(II)] = $8.90 \times 10-7 \mathrm{M}$, [EN]total $=0.00$ to $1.96 \times 10-3 \mathrm{M}, \mathrm{pH}=8.8 \pm 0.1$ and $\mathrm{I}=\mathbf{0 . 0 1} \mathrm{M}(\mathrm{NaNO3})$

Fig. 3: Plot of peak potential vs. log [ E thy lenediamine ] f ree ; $[$ Cadmium(II)] $=0.89 \mu \mathrm{M}, \mathrm{pH}=8.8 \pm 0.1$ and $\mathrm{I}=\mathbf{0 . 0 1} \mathrm{M}$ (NaNO3) 
Fig. 4: The variation of F0 as a function of concentration of free ethylenediamine; [Cadmium(II)] $=0.89 \mu \mathrm{M}, \mathrm{pH}=8.8 \pm 0.1$ and $\mathrm{I}=\mathbf{0 . 0 1} \mathrm{M}\left(\mathrm{NaNO}_{3}\right)$

Fig. 5. Species distribution of ethylenediamine as a function of $\mathrm{pH}$.

Fig. 6. Species distribution of cadmium as a function of concentration of ethylenediamine at pH $8.8 \pm 0.1$ 